\title{
Swimming and grommets
}

\section{Children with grommets should be allowed to swim}

Nearly 40 years after the technique of grommet insertion was reintroduced by Armstrong' otolaryngological advice about whether children with grommets should be allowed to swim still varies from total prohibition to total licence. The theoretical risk is that water will pass through the grommet and infect the middle ear. But does this happen?

Morgan found that after the ears were submerged in a bath for four minutes in only half the cases was there water on the tympanic membrane. ${ }^{2}$ Calculating that water pressures of $12 \cdot 5-22 \cdot 5 \mathrm{~cm}$ would be needed to push water through a grommet, several authors concluded that contamination of the middle ear was unlikely with normal swimming, hair washing, and bathing but that the risk would be increased with diving. ${ }^{3+}$ They suggested that the eustachian tube had to be functioning before water would pass though a grommet, ${ }^{5}$ and Myerhoff et al confirmed this with animal experiments. ${ }^{6}$ Children with glue ear often have impaired function of the eustachian tube, thus making contamination of the middle ear less likely.

If water passes through a grommet does it matter? Over three weeks Smelt and Monkhouse irrigated the middle ear mucosa of guinea pigs with sea water, bath water, swimming pool water, or normal saline (as a control). ${ }^{7}$ Only bath water provoked appreciable inflammation.

In the first prospective trial comparing patients fitted with grommets who did and did not go swimming Chapman found that the rate of otorrhoea was lower in those who swam without using ear plugs than in non-swimmers $(14 \% v 18 \%){ }^{8}$ Since then six further papers have compared rates of infection between swimmers and non-swimmers and found no significant difference. ${ }^{9-14}$ As in Chapman's original study five of these papers reported a lower incidence of otorrhoea in swimmers than non-swimmers. Ear plugs seem to confer no extra benefit, and the muffling of sound and the necessary adult supervision decrease both the fun and the enjoyment of swimming. ${ }^{15}$ The question of whether bath water increases the risk of ear infection in children with grommets has not been studied, though high concentrations of bacteria and irritative substances have been shown in bath water. ${ }^{16}$

Chapman wrote that the advice to forbid swimming in children with grommets "causes distress, delays the acquisition of a life-saving skill and is based on no published evidence." Twelve years and numerous studies later, this statement remains true.

M B PRINGLE

ENT Registrar,

Royal National Throat, Nose, and Ear Hospital,

London WCIX 8DA

1 Armstrong BW. A new treatment for chronic secretory otitis media. Arch Otolaryngol 1954;49:653-4

Morgan NJ. Penetration of water down the external auditory meatus to the tympanic membrane. f Laryngol Otol 1987;101:536-7.

3 Marks NJ, Mills RP. Swimming and grommets. f $R$ Soc Med 1983;76:23-6.

4 Pashley NR, Scholl PD. Tympanostomy tubes and liquids -an in vitro study. $\mathcal{f}$ Otolaryngol 1984;13:296-8.

Marks NJ. Secretory otitis media; grommets and swimming. Clin Otolaryngol 1985;10:1-2

6 Myerhoff WL, Morizono T, Wright CG. Tympanostomy tubes and otic drops. Laryngoscope 1983:93:1022-7.

Smelt GJC, Monkhouse WS. The effect of bath water, sea water and swimming on the guinea pig middle ear. F Laryngol Otol 1985;99:1209-16.

8 Chapman DF. Swimming and grommets. Clin Otolaryngol 1980;5:420.

9 Arcand P, Gauthier P, Bilodeau G, Chapados G, Abela A, Desjardins R, et al. Post-myringotomy care: a prospective study. $\mathcal{F}$ Otolaryngol 1984;13:305-8.

10 Smelt GJC, Yeoh LH. Swimming and grommets. $\mathcal{F}$ Laryngol Otol 1984;98:243-5,

11 el-Silimy O. Bacteriological aspects of swimming with grommets. Clin Otolaryngol 1986;11:323-7.

12 Sharma PD. Swimming with grommets. Scand Audiol Suppl 1986;26:89-91.

3 Wight RG, Jones AS, Connell JA. Three year follow up (1983-86) of children undergoing bilateral grommet insertion in Sheffield. Clin Otolaryngol 1987;12:371-5.

4 Becker GD, Eckberg TJ, Goldware RR. Swimming and tympanostomy tubes. Laryngoscope 1987;97:740-1.

15 Groves J. Grommets and swimming. I $R$ Soc Med 1983;76:6.

16 Robson WL, Leung AK. Swimming and ear infection. $7 R$ Soc Health 1990;110:199-200.

\section{Fiddling with medical negligence}

\section{Forget arbitration and go for no fault}

Britain's system of responding to medical accidents is slow, expensive, inefficient, capricious, and hard to understand. It fails to compensate most of those who are injured ${ }^{12}$ and does almost nothing to reduce the likelihood of the accidents recurring. Lord Pearson's commission recognised most of these faults in the 1970s, ${ }^{3}$ and it is increasingly hard to find anybody who will speak up for the system. The main alternative to tort is a no fault system, and support for such a system has come from many groups and individuals including the $\mathrm{BMA},{ }^{+}$the chairman of the Law Commission, ${ }^{5}$ and members of parliament Rosie Barnes and Harriet Harman.

The government has always held out against the pressure. But the Secretary of State for Health has proposed the introduction of a voluntary system of arbitration in cases of medical negligence to supplement, not replace, the tort system. ${ }^{6}$ The proposal has the advantage to him that he will be seen to be doing something, but it will make minimal impact on the real problems.

The Department of Health may recognise the flimsiness of the solution because in its consultation document it never attempts to define the problem. Instead, it leaps into the details of the scheme. The proposal-borrowed from Lord Griffiths, the law lord ${ }^{7}$-is that rather than go to court both parties would voluntarily submit to arbitration by a panel of two doctors (one nominated by each party) and a lawyer skilled in medical negligence. The panel would work mostly on paper and would apply the same standard of negligence as the courts - that is, that the treatment of the patient was not in accordance with a responsible body of medical opinion. The majority view would prevail, but the lawyer's views would carry greater weight on points of law. The panel could award damages as large as in the courts, and there would be no appeal to the courts except on a point of law.

This system would have no effect on the major problem that most of those injured in medical accidents gain no compensation. ${ }^{12}$ Most are not injured by negligence, and many of those who are never make a claim. Nor would the new system do anything to reduce the incidence of accidents: indeed, the possibility that more cases might be settled 